\title{
Anaplastic Lymphoma Kinase (ALK) Overexpression in Lung Cancer Biopsies - An 18 month study in north western Romania
}

\author{
OVIDIU LAUREAN POP1, CLAUDIA TEODORA JUDEA PUSTA*, CAMELIA LIANA BUHAS ${ }^{1 *}$, ADRIAN SORIN JUDEA ${ }^{1}$, \\ ANCA HUNIADI ${ }^{1}$, CLAUDIA J URCA ${ }^{1}$, MIRCEA SANDOR ${ }^{1}$, BIANCA MARIA NEGRUTIU ${ }^{1}$, BOGDAN ADRIAN BUHAS ${ }^{2}$, \\ ZORAN NIKIN ${ }^{3}$, ANDREI PASCALAU ${ }^{1}$ \\ 'University of Oradea, Faculty of Medicine and Pharmacy, 10, 1 Decembrie Sq., 410073, Oradea, Romania. \\ 2Municipal Clinical Hospital of Oradea, 2 Corneliu Coposu Str., 410450, Oradea, Romania \\ 3University of Novi Sad, Faculty of Medicine, Department of Pathology, Hajduk Veljkova 3, 21000 Novi Sad, Serbia
}

\begin{abstract}
Lung cancer is the first cause of death worldwide of oncological patients. Most of them are non-small cell lung cancer (NSCLC) and many of them are characterized by different molecular markers that allow the development of personalized treatments. Epithelial growth factor receptor(EGFR) and anaplastic lymphoma kinase (ALK) are the most frequently tested genes in lung adenocarcinoma and other lung carcinomas with glandular component. The aim of our study is to evaluate the distribution of ALK gene mutation in lung cancer patient from North West part of Romania. We analysed a number of 289 lung biopsies along 18 months. The samples have been incubated with monoclonal ALK antibodies (clone D5F3), according to the manufacturer's instruction. The interpretation guide provided by manufacturer was used to distinguish the positives vs negative cases. In our study from a total number of 289 lung biopsies, 196 cases were carcinomas. $57.65 \%$ from the total number of lung cancers were adenocarcinomas. A total number of 79 cases have been analysed for ALK gene supra expression. $5.08 \%$ of adenocarcinomas were positive for ALK, but the mean age for this population is higher comparing with the data from other studies.
\end{abstract}

Keywords: lung cancer, IHC, ALK, supra expression, TKI inhibitors

Lung cancer is the first cause of death of oncological patients worldwide, because it is the most common cancer type w orldwide [1, 2]. In the last decade, we have seen an overall decrease in incidence rate by $1-2.5 \%$ of lung cancer. However, adenocarcinoma type presents an increasing trend. Recent statistics regarding lung cancer show a histologic subtype classification in which adenocarcinomas are the most prevalent type (up to 57\%), followed by squamous cell carcinoma (up to $30 \%$ ) and small cell carcinoma (up to $12 \%$ ) and others [1, 3].

The histologic type of lung cancer is an important factor for the determination and choice of future treatment. Personalized therapy nowadays plays more and more a main role in the management of lung non-small cell carcinoma (NSCLC). The genes and chromosomal alteration, such as activating mutations and chromosomal rearrangements, are related with selective targeted therapies and finally with the prognosis. More recently, lung adenocarcinoma cases with translocations in anaplastic lymphoma kinase (ALK) have demonstrated sensitivity to the administration of Tyrosine kinase inhibitor (TKI). In case of squamous cell carcinomas, the cellular immune response is more important in the intratumoral areas [4]. Bottom of Form

The first TKI which was approved by the FDA for the treatment of NSCLC with ALK over-expression was Crizotinib. Crizotinib is aminopyridine-based inhibitor of the receptor tyrosine kinase; 3-[(1R)-1-(2,6-dichloro-3fluorophenyl) ethoxy]-5-(1-piperidin-4-ylpyrazol-4yl) pyridin-2 amine. The molecular weight of the molecule is $450.339 \mathrm{~g} / \mathrm{mol}$ and the chemical molecular formula is presented in (fig. 1) [5, 6].

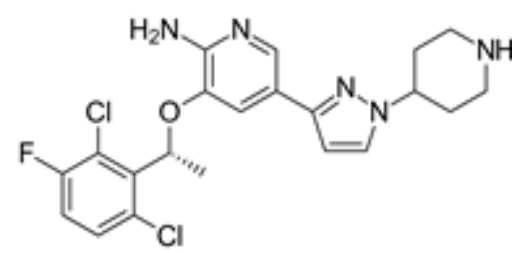

Fig. 1. Crizotinib.

Molecular structure

ALK kinase, ALK fusion protein, c-Met kinase and ROS1 are inhibited by Crizotinib. Also, it plays a role in the c-Met signalling pathway. The o-dealkylation of the drug is metabolized by CYP3A4 and CYP3A5. High-fat concentration meals can reduce the bioavailability following a single $250 \mathrm{mg}$ oral dose [5-7].

An ALK alteration was first discovered in anaplastic largecell carcinomas, as a fusion oncogene with nucleophosmin (NPM). Relatively recently, a team led by Hiroyuki Mano described the fusion between echinoderm microtubule associated protein-like 4 (EML4) and ALK as a somatic gene rearrangement found in a small percentage of Japanese lung cancers $[8,9]$.

Some studies have demonstrated the association between wild-type ALK and its role in the development of the nervous system [10]. In adults, expression of ALK is largely restricted to certain neuronal cells. The signalling pathway of ALK, at cellular level, interferes with other gene drivers, such as: RAS-mitogen-activated protein kinase (MAPK) and phosphoinositide 3-kinase (PI3K) -AKT. The aberrant expression of the ALK fusions in the cytoplasm takes place by the fusion between EML4 and intracellular tyrosine kinase domain of ALK. This results in uncontrolled cellular proliferation and prolonged cell survival [11,12]. 
The percentage of patients with advanced, ALK-positive lung tissue is by far lower in comparison with KRAS mutations (around $25 \%$ of NSCLCS), and EGFR (epithelial grow th factor receptor) mutations (10\% to $15 \%$ of NSCLCs). Other driver genes as ROS1 (a proto-oncogene with similar structure as ALK) and C-MET (also called tyrosine-protein kinase) are even less common than ALK, each present in $1 \%$ to $2 \%$ of NSCLCs [13].

Smoking behaviour is closely associated with ALK [14]. A higher number (15\%) of lung cancer patients, with a personal history not involving any degree of smoking, was analysed in a study from Massachusetts General Hospital [11]. More than $90 \%$ of patients with ALK positive cancer are never - or light smokers. Also, important factors seem to be, according with some studies, the younger age at diagnosis [10]. The presence of chronic diseases, such as cancer, might be a reliable predictor for suicide-related behaviors [15-17].

The aim of this study is to evaluate the distribution of ALK gene mutation in lung cancer patient from North West part of Romania.

\section{Experimental part}

Material and Methods

Tissue specimens were fixed in $10 \%$ buffered formalin ( $p H$ 7.4) for up to 24 hours and paraffin-embedded according to standard procedures. Immunohistochemical analysis was performed on $4 \mu \mathrm{m}$ thick sections prepared from formalin-fixed paraffin - embedded tissue. Immunohistochemical assays were performed on a Ventana Benchmark GX (Ventana Medical Systems Inc., Tucson, AZ, USA) automated staining instrument according to the manufacturer's instructions. Slides were deparaffinized using EZprep solution (Ventana Medical Systems, Inc.) at $90^{\circ} \mathrm{C}$, and all reagents and incubation times were chosen as directed on antibody package inserts. Slides were developed using the Opti View DAB (3,3'- diaminobenzidine) detection kit (Ventana Medical Systems, Inc.) associated with OptiView amplification kit and after that counterstained with haematoxylin and blueing [6,18-24].

The cases sections were incubated with the anaplastic lymphoma kinase-ALK (clone D5F3) rabbit monoclonal antibody [18]. For each case positive control slides were used prepared from appendix tissue as a mean of comparison. Negative control was done by omitting the primary antibody (clone D5F3). The cases were analysed bytwo skilled pathologists according with the interpretation guide approved by the FDA. The total number of cases included in our study is 286 . The inclusion criteria are: all the cases from J anuary 2017 till J une 2018 from the files of the Pathology Department of Municipal Clinical Hospital of Oradea, Romania, with a clear diagnosis of lung cancer, upon biopsy tissue obtained by bronchoscopy and by transthoracic biopsies.

The statistical analysis was performed by using the Microsoft Office Excel and the Chi-Square test for statistical relevance.

\section{Results and discussion}

Our study revealed that from a total number of cancers (196 cases) most of them were adenocarcinomas (57.65\%) followed by squamous cell carcinomas (26.53\%), small cell carcinomas (13.77\%) and large cell carcinomas (2.05\%). When we analysed the cases from gender distribution point of view the results showed that in the female group most of the patients presented adenocarcinomas and the remaining presented small cell carcinoma or other lung cancer types. More specifically there were 47 lung adenocarcinoma cases vs 9 small cell carcinoma cases ( $p$ value $<0.0001$ ). In the male gender group, the majority of the cases belonged to lung adenocarcinoma and, on the last place, were the patients with large cell carcinoma. In fact, 68 male patients presented adenocarcinoma and 18 cases were with small cell lung carcinoma ( $p$ value $<0.0001$ ) (fig. 2).

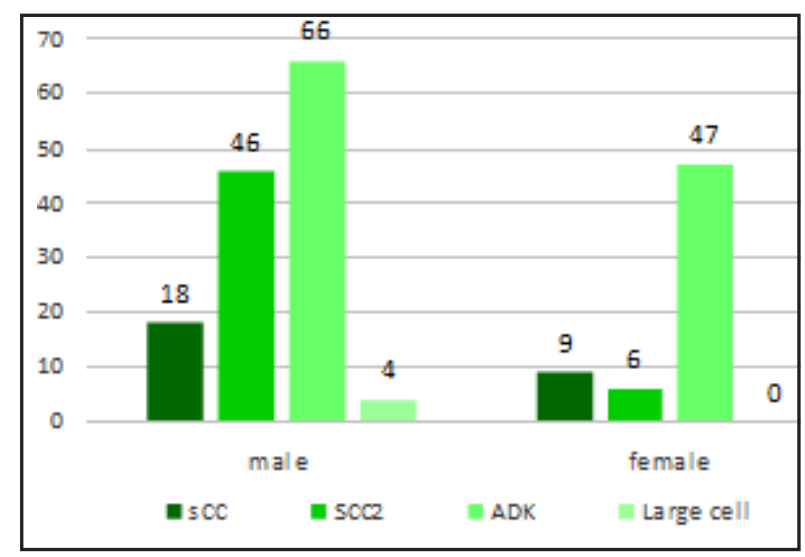

Fig. 2. Dispersion of the cancer types according with gender distribution (the same tendency can be noted in cases involving adenocarcinoma despite the difference in gender, but in regards to squamous cell carcinoma the number of cases is higher in males compared with small cell carcinomas, being quite the opposite in females)

According with the Chi-Square test, we concluded that there is a high degree of association between the gender of the patients and the lung cancer type found in our study. In our study, we analysed also the correlation between the patients with lung adenocarcinoma and their age distribution pattern. In our study, the average age was 63 years, with 9.1 standard deviation. In the next chart, the age distribution pattern in patients with lung adenocarcinoma can be examined (fig. 3).

From the gender distribution point of view, our study revealed that most of the patients with lung adenocarcinoma were males, with a male/female ratio 1.43:1. From the total number of lung adenocarcinomas (113 cases), we tested for ALK mutation (D5F3 clone) 79 cases, by immune-histochemistry tests. According with our results, 4 cases were positive. It means that $5.08 \%$ from all the tested lung adenocarcinomas presented ALK

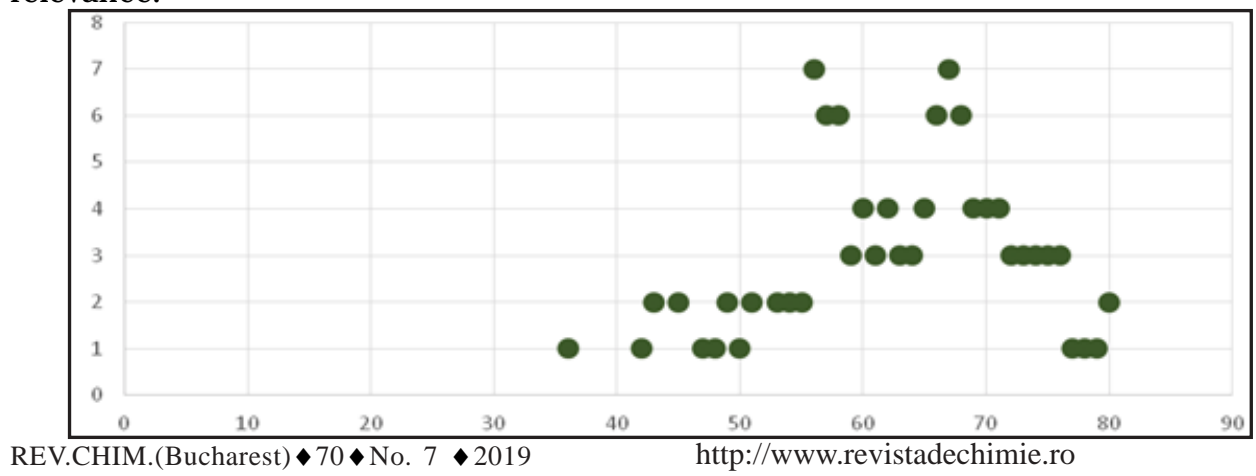

Fig. 3. Age distribution in patients with lung adenocarcinoma (the average age is 63 years. It means that most of the ages are located close to this line. The standard deviation is 9.1 years). 
expression. All the cases were set as positive ALK-cases only if they correctly fulfilled the Ventana ALK interpretation Guide. According with the guide, cases should be regarded as positive when, on microscope examination, a strong granular cytoplasmic staining is present in tumour cells. There is no cut-off for positive tumour cells (fig. 4). Each cell that fulfils the guide criteria is a positive case.

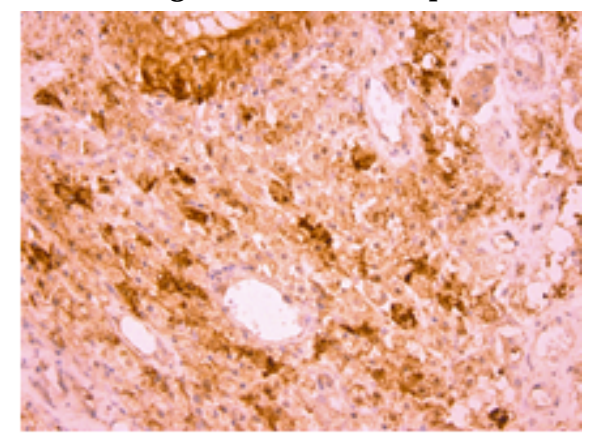

Fig.4. Highly intense granular cytoplasmic ALK (D5F3) staining in case of lung adenocarcinoma (20X) (The microscopic image shows a granular cytoplasmic staining in tumour cells. The positivity is done by reaction with DAB chromogen and appears as a darkbrown staining. Any percentage of positive tumour cells is taken

into account. The pictures were captured by 20X objective).

After analysing the correlation between the gender ratio and the lung adenocarcinoma rate of presence, we noted that double of the positive ALK cases belonged to the female group (8:4). The average age of the female which presented ALK mutation was 56.37 years (minimum age was 36 and maximum age was 73), compared with male average age ALK mutation cases with age span ranging in between 66.75 years ( 59 to 72 years). From the total number of tested cases (79), 43 were males and 32 females. When the percentage of positive cases were analysed for gender correlation, our results showed that $25 \%$ were female patients with lung adenocarcinoma and only $10.75 \%$ cases were males with lung adenocarcinoma.

Upon comparison with other similar studies, our cases presented similarities in the presence and distribution of adenocarcinoma histologic subtype, but on the contrary, our study showed a slow increase in the percentage of cases with small cell lung carcinoma. Our hypothesis is that this difference can be due to a different demographic distribution or due to differentsmoking behaviours. Another explanation can be the different number of cases included in the studies.

Younger patients, with light-smoking or non-smoking behaviour are commonly associated with ALK. In our study, the overall positive cases were $15.18 \%$. All the positive ALK cases from our study presented a non-smoking personal history. According with other studies done at Massachusetts General Hospital, close to $15 \%$ of lung cancers from patients with a non-smoking history are ALK positive [10].

The incidence of EML4-ALK translocation in nonsmoking female patients with adenocarcinomas is higher $(15.2 \%)$ like in general population. The ALK rearrangements are correlated with adenocarcinoma subtypes too. Some studies show that mucinous cribriform pattern and solid signet-ring cell pattern are more prone to be positive $[25,26]$. Dysregulated ALK expression is not only associated with lymphomas and lung cancer but can be identified as a driver mutation in nearly twenty different human other malignancies. In the non-small cell lung cancers (NSCLC) the percentage ranges from $4 \%$ to $9 \%$ [10, 27-29]. There are now over 20 ALK fusion partners identified in NSCLC. EML4 represents the commonest fusion partner with $29 \%-33 \%$ of gene fusions identified to this day [30].

Most of the studies concluded that the median age of patients with ALK expression is lower than the rest of cases involving NSCLC [30]. In our study, the median age in females was 56.37 and was with $10 \%$ more in males. If we consider females and males combined the average age is 61-56 years despite that is 5-8 years higher like in other studies. Analysis of only the non-smoker and young patients from the ALK rearrangement point of view frequency showed up to $17 \%[28,31,32]$. In our study, the positive results were higher $(25 \%)$ in the female patients with lung adenocarcinoma. We do nothave any explication for these results yet. We have an ongoing study to find out any possible different demographic futures. For the male patients positive to ALK the percentage was much lower.

Several antibodies for the detection of the expression of ALK in tissues are on the market right now, but only few are approved by the FDA to be used as a companion diagnostic test for ALK inhibitors treatment. IHC is the best option to detect the ALK expression, especially when the sample is small (few cells) [33,34]. Nowadays, it has been proved that ALK IHC is a better test compared to ALK FISH for predicting response to ALK inhibitors [35]. Patients with ALK IHC positive results have been responding to TKI therapy even when the FISH test was negative [36,37].

The first line of treatment with Crizotinib in non-small cell lung carcinomas improves both; the PFS to 10.9 from 7.0 month; $p<001$, and the ORR monoclonal therapy vs chemotherapy (74\% vs. $45 \%$; $p<001)$ [38]. Another important issue is to achieve the Crizotinib optimal dose for the patients. The CYP3A (Cytochrome P450 substrate) inhibitors increase the drug plasma concentration. Some examples of strong inhibitors of CYP3A are drugs used in the treatment of viral infection or serious fungal infections [39-42].

The limitations of our study are its retrospective nature and the small number of cases ( 79 patients tasted for ALK mutation).

\section{Conclusions}

According with our data, we concluded that the study should be extended to see if the higher ALK + cases are a feature of the population from our region or the number or cases taken in account is less than enough.

\section{References}

1.FERLAY, J., SOERJ OMATARAM, I., DIKSHIT, R., ESER, S., MATHERS, C., REBELO, M., PARKIN, D.M., FORMAN, D., BRAY, F., Int. J. Cancer, 136, no. 5, 2012, p. 359.

2.J EMAL, A., BRAY, F., CENTER, M.M., FERLAY, J., WARD, E., FORMAN, D., CA Cancer J. Clin., 61, no. 2, 2011, p. 69.

3.PARASCHIV, B., TOMA, C.L., DIACONU, C.C. Archivos de Bronconeumología, 49, no. 7, 2013, pp. 315-316.

4.POP, O., BEMBEA, M., PUSTA, C., PASCALAU, A., Virchows Arch., 471, Suppl. 1, Meeting Abstract: PS-06-029, 2017, p. S118.

5.SAHU, A., PRABHASH, K., NORONHA, V., JOSHI, A., DESAI, S., South Asian J. Cancer, 2, no. 2, 2013, p. 91.

6.GOLDING, B., LUU, A., JONES, R., VILORIA-PETI, A.M., Mol. Cancer, 17, no. 1, 2018, p.1.

7.ZOU, H.Y., LI, Q., LEE, J.H., ARANGO, M.E., MCDONNELL, S.R., YAMAZAKI, S., KOUDRIAKOVA, T.B., ALTON, G., CUI, J.J., KUNG, P.P., et al., Cancer Res., 67, no. 9, 2007, p.4408.

8.SODA, M., CHOI, Y.L., ENOMOTO, M., TAKADA, S., YAMASHITA, Y., ISHIKAWA, S., FUJIWARA, S., WATANABE, H., KURASHINA, K., HATANAKA, H., BANDO, M., OHNO, S., ISHIKAWA, Y., ABURATAN, I H., NIKI, T., SOHARA, Y., SUGIYAMA, Y., MANO, H., Nature, 448, 2007, p. 561-6. 
9.INAMURA, K., TAKEUCHI, K., TOGASHI, Y., NOMURA, K., NINOMIYA, H., OKUI, M., SATOH, Y., OKUMURA, S., NAKAGAWA, K., SODA, M., CHOI, Y.L., NIKI, T., MANO, H., ISHIKAWA, Y., J. Thorac. Oncol., 3, no. 1,2008, p.13.

10.CHIARLE, R., VOENA, C., AMBROGIO, C., PIVA, R., INGHIRAMI, G., Nat. Rev. Cancer, 8, 2008, p.11.

11.SHAW, A.T., ENGELMAN, J.A., J . Clin. Oncol., 31, no. 8, 2013, p.1105. 12.DIACONU, C., DUMITRU, N., FRUNTELATA, A., LACAU, S., BARTOS, D. Acta Cardiologica Sinica, 31, no.1, 2015, pp. 83-86.

13.BERGETHON, K., SHAW, A.T., OU, S.H., KATAYAMA, R., LOVLY, C.M., MCDONALD, N.T., MASSION, P.P., SIWAK-TAPP, C., GONZALEZ, A., FANG, R., MARK, E.J ., BATTEN, J.M., CHEN, H., WILNER, K.D., KWAK, E.L., CLARK, J.W., CARBONE, D.P., JI, H., ENGELMAN, J.A., MINOKENUDSON, M., PAO, W., IAFRATE, A.J. , J. Clin. Oncol., 30, 2012, p. 863.

14.DIACONU, C.C., ARSENE, D., PARASCHIV, B., BALACEANU, A., BARTOS, D. Acta Endocrinologica, IX, no. 4, 2013, p. 637-642.

15.J OSHI, P., SONG, H.B., LEE, S.A., Indian J Psychiatry, 59, no. 3, 2017, p.352.

16.MIHALACHE, G., BUHA', C., RAHOTÃ, D., Rom. J. Leg. Med., 19, no. 1, 2011, p. 69

17.J UDEA-PUSTA, C., RUSU, A., CAMARASAN, A., Aggress. Violent Behav., 47, 2019, p.68. https://doi.org/10.1016/j.avb.2019.03.006 18.SCROBOTA, I., BOLFA, P., FILIP, A.G., CATOI, C., ALB, C., POP, O., TATOMIR, C., BACIUT, G., J. Physiol. Pharmacol., 67, no. 1, 2016, p. 161.

19.CHAFIN, D., THEISS, A., ROBERTS, E., BORLEE, G., OTTER, M., BAIR, G.S., J.PLoS One, 8, no. 1, 2013, p. e54138.

20.PUSTA, C.T., MIHALACHE, G., BUHAS, C., POP, O., Rom. J. Leg. Med., 23, no. 4, 2015, p. 247

21.PALLAG, A., ROSCA, E., TIT, D.M., MUTIU, G., BUNGAU, S.G., POP, O. L., Rom. J. Morphol. Embriol., 56, no. 3, 2015, p. 1103.

22.MOGOANTA, S.S., COSTACHE, A., MUTIU, G., BUNGAU, S.G., GHILUSI, M., GROSU, F., VASILE, M., VILCEA, I.D., GHERGHINESCU, M.C., MOGOANTA, L., ION, D.A., Rom. J. Morphol. Embriol., 56, no. 2 Suppl., 2015, p. 511.

23.ENDRES, L., TIT, D.M., BUNGAU, S., CIOCA, G., ABDEL-DAIM, M., BUHAS, C., POP, O., SAVA, C., Rev. Chim.(Bucharest), 69, no. 12, 2018, p. 3675.

24.ENDRES, L., UIVAROSAN, D., TIT, D.M., POP, O., BUNGAU, S., BUHAS, C., Iran. J. Public Health, 47, no. 4, 2018, p. 606.

25.LI Y., LI Y., YANG T., WEI S., WANG J., WANG M., WANG Y., ZHOU Q., LIU H., CHEN J. PLOS One, 8, no. 1, 2013, p. e52093.

26.DIACONU, C.C., ARSENE, D., BALACEANU, A., BARTOS, D. Romanian J ournal of Morphology and Embryology, 55, no. 3, 2014, pp. 973-976. 27.SHACKELFORD, R.E., VORA, M., MAYHALL, K., COTELINGAM, J., Genes. Cancer, 5, no. 1-2, 2014, p. 1.

28.SHAW, A.T., YEAP, B.Y., MINO-KENUDSON, M., JAFRATE, A.J . DIGUMARTHY, S.R., COSTA, D.B., HEIST, RS.., SOLOMON, B., STUBBS, H., ADMANE, S., MCDERMOTT, U., SETTLEMAN, J., KOBAYASHI, S., MARK, E.J ., RODIG, SJ ., CHIRIEAC, L.R., KWAK, E.L., LYNCH, T.J ., IAFRATE, A.J., J. Clin, Oncol., 27, no. 26, 2009, p. 4247.
29.KOIVUNEN, J.P., MERMEL, C., ZEJ NULLAHU, K., MURPHY, C., LIFSHITS, E., HOLMES, A.J., CHOI, H.G., KIM, J., CHIANG, D., THOMAS, R., LEE, J., RICHARDS, W.G. SUGARBAKER, D.J., DUCKO C., LINDEMAN, N., MARCOUX, J.P., ENGELMAN, J.A., GRAY, N.S., LEE, C., MEYERSON, M., JÄNNE, P.A., Clin. Cancer Res., 14, no. 13, 2008, p. 4275.

30.SASAKI, T., RODIG, S.J ., CHIRIEAC, L.R., J ANNE, P.A., Eur. J. Cancer., 46, no. 10, 2010, p. 1773.

31.CHIA, P.L., MITCHELL, P., DOBROVIC, A., JOHN, T., Clinical Epidemiology, 6, 2014, p. 423.

32.BARLESI, F, MAZIERES, J., MERLIO, J.P., DEBIEUVRE, D., MOSSER, J., LENA, H., OUAFIK, L., BESSE, B., ROUQUETTE, I., WESTEEL, V., ESCANDE, F., MONNET, I., LEMOINE, A., VEILLON, R., BLON,S H., AUDIGIER-VALETTE, C., BRINGUIER, P.P., LAMY, R., BEAU-FALLER, M., PUJ OL, J.L., SABOURIN, J.C., PENAULT-LLORCA, F., DENIS, M.G., LANTUEJ OUL, S., MORIN, F., TRAN, Q., MISSY, P., LANGLAIS, A., MILLERON, B., CADRANEL, J., SORIA, J., ZALCMAN, G., Lancet, 387, 2016, p. 1415.

33.THUNNISSEN, E., ALLEN, T.C, ADAM, J ., AISNER, D.L., BEASLEY, M.B., BORCZUK, A.C., CAGLE, P.T., CAPELOZZI, V.L., COOPER, W., HARIRI, L.P., KERN, I., LANTUEJ OUL, S., MILLER, R., MINOKENUDSON, M., RADONIC, T., RAPARIA, K., REKHTMAN, N., ROYCHOWDHURI, S., RUSSELL, P., SCHNEIDER, F., SHOLL, L.M., TSAO, M.S., VIVERO, M., YATABE, Y., Arch. Pathol. Lab. Med., 140, 2017, p. 341.

34.TATARU, A.L., FURAU, G., AFILON, J., IONESCU, C., DIMITRIU, M., BRATU, O.G., TIT, D.M., BUNGAU, S., FURAU, C., J. Clin. Med., 8, no. 1, 2019, 96. https://doi.org/10.3390/jcm8010096

35.VAN DER WEKKEN, A.J., PELGRIM, R., 'T HART, N., WERNER, N., MASTIK, MF., HENDRIKS, L., VAN DER HEIJDEN, E.H.F.M., LOOIJ ENSALAMON, M., DE LANGEN, A.J., STAAL-VAN DEN BREKEL, J., RIEMERSMA, S., VAN DEN BORNE, B.E., SPEEL, E.J .M., DINGEMANS, A.C, HILTERMANN, T.J.N., VAN DEN BERG, A., TIMENS, W., SCHUURING, E., GROEN, H.J.M., Clin. Cancer Res., 23, no. 15, 2017, p. 4251. 36.CIUHU, A.N., RAHNEA NITA, R.A., POPESCU, M., DUMITRU BADIU, C.D., PANTEA STOIAN, A.M., LUPULIASA, D., GHERGHICEANU, F., DIACONU, C.C., RAHNEA NITA, G. Evidence of strong opioid therapy for palliation of breathlesness in cancer patients. Farmacia, 65, no. 2, 2017, pp. 173-178.

37.BALACEANU, A., DIACONU, C., MATEESCU, D., STANICA, A. Medical Ultrasonography, 12, no. 4, 2010, pp. 345-348.

38.XIA, B., HERBST, R.S., In: TANOUE, L., DETTERBECK, F. (Eds). Lung Cancer: A Practical Approach to Evidence-Based Clinical Evaluation and Management, Elsevier Inc., 2018, p. 99-115.

39.GERSON, S.L., CAIMI, P.F., WILLIAM, B.M., CREGER, R.J., in: HOFFMAN, R., SILBERSTEIN, L.E., SALAMA, M.E., BENZ, E.J. J.R, HESLOP, H.E., ANASTASI, J., ABUTALIB, S.A. (Eds). Hematology: Basic Principles and Practice, 7th Edition, Elsevier Inc., 2018, p. 849-912.

40.ABDEL-DAIM, M.M., ABO-EL-SOOUD, K., ALEYA, L., BUNGAU, S.G., NAJ DA, A., SALUJA, R., Oxid. Med. Cell. Longev, 2018, 2018, ID 6276438. https://doi.org/10.1155/2018/6276438

41.ABDEL-DAIM, M.M., ZAKHARY, N.I., ALEYA, L., BUNGAU, S.G., BOHARA, R.A., SIDDIQI, N.J., Oxid. Med. Cell. Longev., 2018, 2018, ID 2098123. https://doi.org/10.1155/2018/2098123

42.ABDEL-DAIM, M.M., EL-TAWIL, O.S., BUNGAU, S.G., ATANASAOV, A.G., Oxid. Med. Cell. Longev., 2019, 2019, ID 4179676. https://doi.org/ $10.155 / 2019 / 4179676$

$\overline{\text { Manuscript received } 16.10 .2018}$ 